\title{
IMPACT OF BASALT BASED THREAD LININGS ON THE TRIBOLOGICAL PARAMETERS OF THE CLUTCH LININGS FOR MOTOR VEHICLES
}

\author{
Darko Danev, Simeon Simeonov, Vase Jordanoska
}

Professional paper

Friction clutches are still the most widely used type of coupling especially in passenger vehicles. Structural construction of friction clutches is not changed significantly, but their performance is what is constantly being improved. Among other factors that determine the life of the friction clutch i.e. of the friction disk is the quality and friction characteristics of linings. This paper presents the results of experimental research of the impact of the material composition of the linings on the tribological parameters. Specifically are shown the improvements that can be achieved with the use of basalt thread in the material composition of the friction linings.

Keywords: basalt thread; clutch; lining; material composition; testing methodology; tribological parameters

Utjecaj obloga izrađenih od bazaltnog vlakna na tribološke parametre obloga spojki motornih vozila

Stručni članak

Tarne (frikcijske) spojke su još uvijek najviše upotrebljavani tip kvačila naročito u putničkim vozilima. Konstrukcija tarnih spojki se značajno ne mijenja, ali se njihove performanse stalno poboljšavaju. Među čimbenicima koji utječu na vijek trajanja tarne spojke t.j. tarnog (frikcijskog) kotača su kvaliteta i tarne karakteristike obloge. U radu se daju rezultati eksperimentalnog istraživanja utjecaja sastava materijala obloge na tribološke parametre. Posebno se pokazuju poboljšanja koja se postižu primjenom bazaltnog vlakna u sastavu materijala tarnih obloga.

Ključne riječi: bazaltno vlakno; metodoligija ispitivanja; obloga; sastav materijala; spojka; tribološki parametri

\section{Introduction}

The clutch is a friction mechanism which is installed between the engine and the gearbox. It transfers the torque from the driving to the driven part.

The main reason for insufficient life of the clutch is sliding [2] in the engaging/disengaging process $[3,5]$ and overload of the clutch. In order to increase the life of the clutch friction disk, the largest efforts are made to improve the quality of the friction lining, which should meet lots of requirements.

Friction material is one of the significant bearers of characteristics of the clutch. Change in the material of motor vehicle clutches implies a need of various procedures for quality control. Friction with its variable nature depends on various factors, on the characteristics of the friction components and on the constructive characteristics of the clutch. Therefore in the development process of the friction clutch, or the friction material, quality is determined by testing.

The most spread way of testing of the friction materials is testing on the basis of a sample. Information about the characteristics of the friction material tested in this way does not provide realistic results. This test is still used by manufacturers of friction materials as a way to maintain quality with a large use of the acquired experience in the production.

Another way of testing friction materials (linings) is testing of clutch. It comprises exploitation and laboratory testing [8]. Exploitation tests are long term and expensive, while laboratory tests are short-term and cheaper.

\subsection{Aim and objective of the research}

The aim of the research is to improve the performance of friction linings in clutches. Also it is important that optimal economic effects are achieved in terms of the benefits of basalt based thread use. This thread type is part of the developmental research of linings' manufacturers. In addition, the impact of other substances and their ratio in the material structure from which friction linings are produced, are appreciated. It is important that the new product satisfies the criteria for friction linings, in both functional and environmental terms, which is currently emphasized in this area.

\subsection{Aim and objective of the research}

On the basis of the aforesaid for the subject of research, the following activities were covered:

- Studying the available knowledge and experiences in the subject area (available literature, manufacturers' brochures and own experiences);

- Designing a research methodology;

- Experimental research;

- Analysis of results and conclusions.

\section{Copyright transfer agreement}

\subsection{Friction clutch - general considerations}

In order to study friction materials, it is necessary to know the working conditions to which they are exposed during the engagement / disengagement of the clutch. Friction material should meet the clutch working requirements.

The main function of the friction clutch is to transmit the torque from the driving to the driven part, meaning that the clutch is placed between the engine and the gearbox. Other tasks of the clutch are:

- To provide an optimal way of establishing connection between the engine and transmission when the vehicle starts moving.

- To enable a continuous torque transmission. 
- To ensure disconnection between the engine and the transmission when starting the engine, gear change and vehicle braking.

To limit the torque that burdens the transmission by the sliding process. In that way, it serves as a safety element and protects the transmission from overload.

\subsection{Characteristics of the friction materials}

Requirements for the friction linings may be met by different types of materials, different composition and different processes of production [7].

It should be kept in mind that the composition and particularly the manufacture technology of friction materials is a secret of the manufacturers. Therefore, this cannot be used as a basis for assessment in the choice.

Thus, it is easier to compare the material composition with the same material composition and different production technology, which gives different characteristics of the friction material, especially under certain operating conditions.

Friction material should meet the following basic requirements:

- $\quad$ stable friction;

- resistance to wearing;

- $\quad$ good heat conductivity;

- good physical characteristics;

- $\quad$ easy for processing;

- large value of the friction coefficient at increased pressure and temperatures;

- good adhesion to the metal parts.

Beside the large variability of the friction materials, depending on some of the important characteristics or purposes, several subgroups may be formed: Woven cotton, Threaded asbestos, Formed asbestos, Sinter metal, Metal-ceramic materials, Asbestos-free materials (glass fibres, steel fibres, aramid fibres, carbon fibres).

Friction materials may be generally divided into 2 groups:

- asbestos materials and

- $\quad$ asbestos-free materials.

Both types of materials have the same structure in common, determined by four basic components:

- $\quad$ thread (thread net - presents set of all fibres found in the thread);

- $\quad$ filling compound (filler);

- binding compound;

- friction modifiers.

Thread consists of the following components: core fibres (glass, asbestos, carbon, etc.), organic materials (cotton, viscose, etc.) and metal (copper, brass). Fig. 1 shows the structure of glass based thread, in which also are included viscose fibres, cotton fibres and copper wires (one, two or three).

All of these components have their specific function in the composure of the friction material.

Primary the core fibre should provide the mechanical properties, i.e. the strength and the tenacity. In addition, the other fibres provide bonding of all components in the mixture in the production stage, which allows further chemical and physical shaping of the lining. The core fibre can be asbestos (not in use), synthetic organic fibre (PAN, KEVLER, NOMEX; their durable temperature is $180-230-300^{\circ} \mathrm{C}$ ), inorganic chemical fibre (glass, ceramics, steel) and carbon fibres which have special properties and high cost (stable at high temperature, up to $\left.2500{ }^{\circ} \mathrm{C}\right)$.

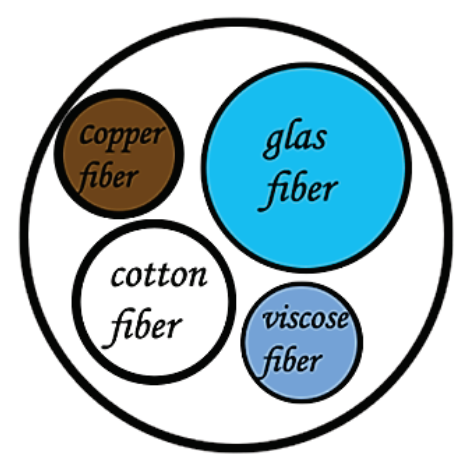

Figure 1 Structure of the glass based thread

Filler has to fill up the mixture of the friction material, i.e. to provide the necessary volume according to the requirements of the technical documentation. Since the filler has no influence on the properties of the friction material, for this purpose, cheaper materials are used. It is important that the filler hardness is not very high because it can affect the properties of the material.

The binding compound is important because it combines all components into a whole and provides the necessary mechanical properties. This can be met by a variety of materials, but generally they require certain procedures of thermal processing or polymerization.

Friction modifiers should provide the relation between the more important characteristics of the friction material, especially regarding the friction and wear. For this purpose materials from different origins are used (minerals, metals, organic resins in different forms and with different shares in the mixture).

Another division, which is often used for linings depending on its composition, is that the friction material is composed of a thread and impregnate. Fillers, modifiers and the binding substance compose the impregnate. Latex is used as a binding substance, which should be resistant to high temperature; otherwise it would soften the lining and would cause sticking to the flywheel and to the pressure plate. The latex is added to the other components (fillers and modifiers) in the proper percentage of weight, which improves the quality of the impregnate i.e. the quality of the lining.

Asbestos based thread consists of asbestos as a base (flexible and solid woven) twisted around a copper (brass) wire and it has good wear resistance and a stable friction coefficient.

Glass based thread is composed of glass fibres (more fibres), organic fibres (viscose, cotton, etc.), and a metal wire (copper, brass) which are spun. A larger percentage of glass in the thread gives a higher friction coefficient and less specific wear. More organic substances in the thread composition allow more impregnate, and hence the friction coefficient is smaller, but the wear is greater [6]. 
Metal wire conducts the heat from the lining to the flywheel, pressure plate and to the environment. The number of the thread reeling on meter length affects how much impregnate the thread will receive. The larger the number of reeling the thread receives, the less impregnate and vice versa. A larger percentage of impregnate in lining has a lower friction coefficient and greater wear. An important parameter in lining composition is the ratio of organic and inorganic substances. More organic substances mean lower friction coefficients and greater wearing and vice versa.

Basalt threads - Basalt is a mineral found on the surfaces near volcanoes. Its colour varies from dark grey to black and it is found in different shapes. This mineral is used in making of roads, but also for linings manufacture by a certain manufacture technology for threads that may replace glass filaments.

A very thin basalt thread has the following characteristics:

- Density $23 \div 25 \mathrm{~kg} / \mathrm{m}^{3}$

- Coefficient of heat conductivity $0,04 \div 0,1 \mathrm{~W} / \mathrm{m} \cdot{ }^{\circ} \mathrm{K}$

- Working temperature $700 \div 1000{ }^{\circ} \mathrm{C}$

- Thermal and sound isolation, resistance to vibrations.

\section{Experimental research of the thread in the basalt based lining}

In order to determine the impact of the lining content on the abrasive and adhesion events and to determine tribological parameters of the lining with experimental tests, different samples of linings on basalt basis were made [4]. Factors that were found as significant in the lining were: the thread-impregnate ratio, the structure of the impregnate, the thread type, the weaving pattern of the thread and the different modifiers.

Samples were produced for freight vehicles, in order to determine the possibilities of use of basalt based thread. It is used as a binding agent based on water dispersions synthetic latex (there are other binding agents on the basis of rubber and resin), whereas as starting point the following knowledge was incorporated.

- The friction coefficient and wearing coefficient depend on the interrelation of the thread and impregnate. By increasing the percentage of impregnate relative to the thread in the lining composition, the friction coefficient will decrease and the wear of the lining will increase. But also, lining price is higher if it contains more thread.

- Impregnate in its composition is latex based and has other added components such as: graphite, sulphur, resins, soot and others. It should be resistant to high temperatures to avoid adhesion of the friction surfaces. In order to determine optimal tribological parameters, composition is changed. There are two things that can be changed in impregnate: one - the latex (two possible qualities) and two - the percentage of the remaining components. Two types of latex are used, Latex 2 which gave negative results in terms of adhesion and Latex 1 which gave positive results in terms of adhesion, but with the proper ratio of components. It is highlighted because with inappropriate ratio in the components and latex 1, negative results are also obtained. The main components of latex are butadiene (that is soft and provides stickiness, $14 \div 30 \%$ ), acrylonitrile $52 \div 72 \%$ and styrene up to $9 \%$ (these two give hardness of the latex). To increase the resistance of the latex at high temperature sulphur is added, phenol resin gives strength, and graphite sticks well and supports the thickening of latex.

- The thread type is determined on the basis of different thread types for a standard impregnate. The change in the thread consists of the change in the number of components and their ratio in percentage. Structure of the thread:

- Basalt (2 fibres), acrylonitrile, viscose (2 fibres), copper (2 wires), with different percentages of the included components more variants of thread are derived;

- Basalt, viscose (2 fibres) copper (3 wires).

- The weaving pattern of the thread is determined in such a way that there is no adhesion between the friction surfaces. Method of weaving:

- Thread elements (acrylonitrile, copper and viscose) are parallel in the thread (yarn), except for basalt fibres which are mutually twisted.

- From the thread elements basalt is twisted alone; acrylonitrile, viscose and one copper wire are parallel [6] and the other copper wire is twisted around these 3.

- Thread elements (yarn) are all together twisted.

From the thread elements, basalt and viscose are parallel and copper wires are twisted around them [6]. This variant gave best results (Fig. 2).

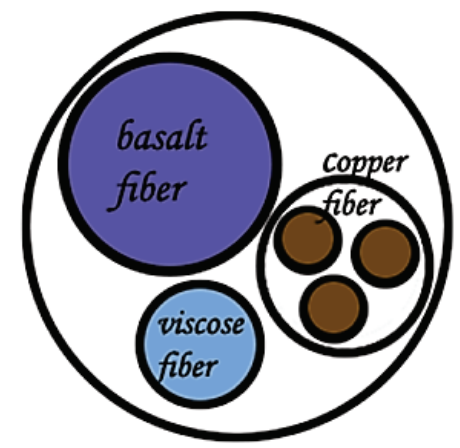

Figure 2 Best weaving pattern of the basalt based thread

- The modifiers have influence on the tribological parameters of the lining, on the stability of the friction coefficient during one cycle and on the stability to increase the numbers of clutch engagement [3].

- The weaving pattern of the lining is spiral (Fig. 3a and $3 \mathrm{~b}$ ) and in zig-zag pattern (Fig. 3c and 3d), for heavy road vehicles zig-zag pattern is used and for passenger vehicles both spiral and zig-zag patterns are used.

The regime of testing is carried out on linings with dimensions $\varnothing 350 / \varnothing 195 / 3,5$. This lining is used in clutches of a larger group of vehicles that are exploited on roads and thus there is a possibility for required tests to be done on the test bench (Tab. 1).

Table 1 Testing regime for a lining with $\varnothing 350 / \varnothing 195 / 3,5$

\begin{tabular}{|l|c|c|c|c|}
\hline \multicolumn{1}{|c|}{ Testing regime } & Unit & Test I & Test II & Test III \\
\hline Number of rotations & $1 / \mathrm{min}$ & 1600 & 1600 & 1900 \\
\hline Specific workload & $\mathrm{J} / \mathrm{cm}^{2}$ & 46 & 107 & 323 \\
\hline Frequency of engagement & $1 / \mathrm{min}^{2}$ & 1,5 & 1,5 & 1,1 \\
\hline Thermal loading & $\mathrm{W} / \mathrm{cm}^{2}$ & 1,15 & 2,67 & 6 \\
\hline Number of cycles & - & 1500 & 1500 & 50 \\
\hline
\end{tabular}

Test I: normal loading, specific sliding work of $40 \div$ $60 \mathrm{~J} / \mathrm{cm}^{2}$, 
- $\quad$ Test II: heavy loading, specific sliding work of $80 \div$ $100 \mathrm{~J} / \mathrm{cm}^{2}$,

- Test III: thermal loading, $q=6 \mathrm{~W} / \mathrm{cm}^{2}$, friction coefficient of $\mu>0,22$ and $N>50$ cycles.

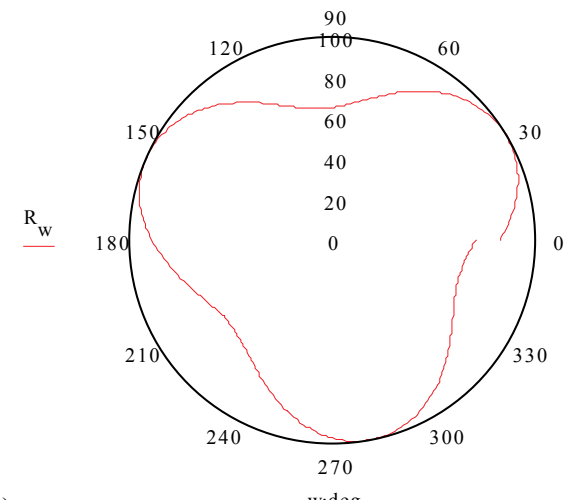

a)

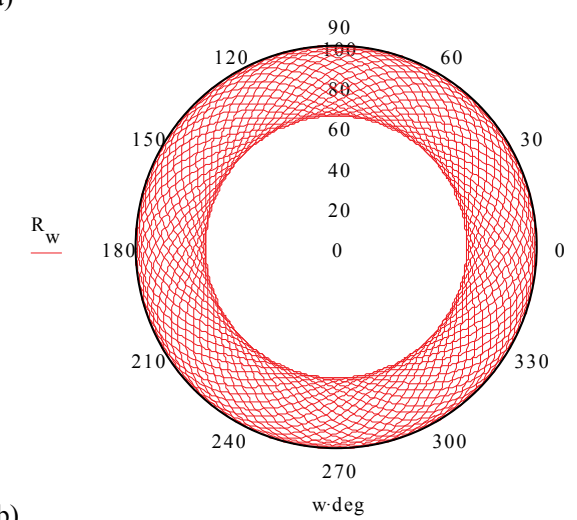

b)

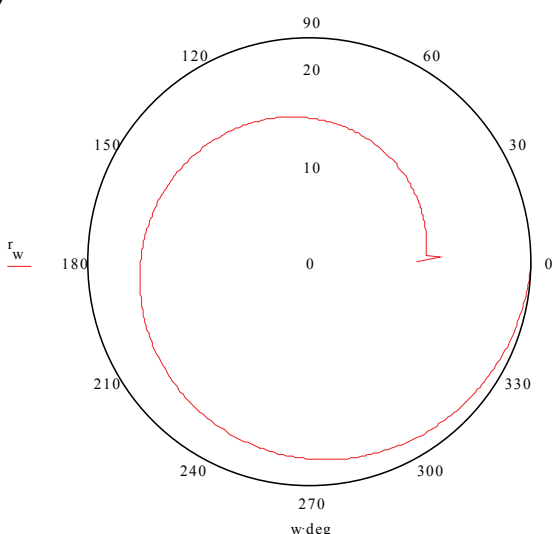

c)

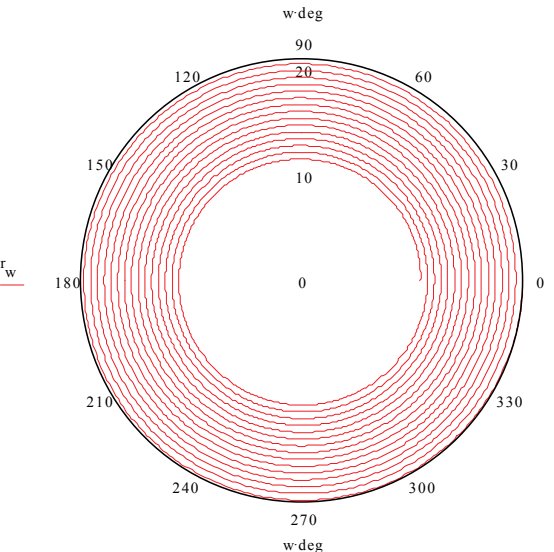

d)

Figure 3 Waving pattern of linings

The test I has determined tribological parameters under normal operating conditions, vehicles are on average $80 \%$ loaded with temperature between friction surfaces of $t \approx 150^{\circ} \mathrm{C}$. The test II determines tribological parameters of lining in heavy operating conditions; vehicles are $20 \%$ loaded on average with temperature between friction surfaces of $t \approx 250{ }^{\circ} \mathrm{C}$. The test III determines if sticking (adhesion) of lining metal parts can be avoided at a temperature of $t \approx 360{ }^{\circ} \mathrm{C}[1]$.

Activities for realization of testing were as follows:

- Fifteen types of basalt based linings with $\varnothing 350 \mathrm{~mm}$ were made (with different combinations of thread, impregnate and waving pattern). They were tested on the test bench for clutches (running of inertia masses).

- Testing regimen A was used in the first part, (test III - thermal loading).

- Tribological parameters of friction linings were tested in the second part - testing regimen B (test II and test I), on a lining with $\varnothing 350 \mathrm{~mm}$ and comparing the results obtained with glass thread based linings.

Both regime parameters ( $\mathrm{A}$ and $\mathrm{B}$ ) are based on test regimes of world clutch manufacturers, standards and on the technical possibilities of the test bench.

The operating principle of the test bench consists of clutch mechanical stress by means of dissipation of a certain amount of kinetic energy during each engagement. It is done by clutch operation in mode of running inertia masses and their braking. A high degree of simulation of real working conditions is thus achieved.

First the basalt based linings were tested by test III, in order to see which linings will meet the requirement that no abrasive-adhesive events occur, and that the friction coefficient is larger than 0,22 . The lining on a basalt base that met this requirement is $\mathrm{T} 1$, with its composition samples manufactured for tribological tests.

RESULT 1: from the laboratory testing of a clutch Dimensions: $\varnothing 350 / \varnothing 195 / 3,5$; Lining quality: T1

\begin{tabular}{|c|c|c|}
\hline Testing regime & Test I & Test II \\
\hline Number of rotations $(1 / \mathrm{min})$ & 1600 & 1600 \\
\hline Moment of inertia $\left(\mathrm{kg} \cdot \mathrm{m}^{2}\right)$ & 4,42 & 10,22 \\
\hline Specific workload $\left(\mathrm{J} / \mathrm{cm}^{2}\right)$ & 46 & 107 \\
\hline Frequency of engagement (1/min) & 1,5 & 1,5 \\
\hline Specific thermal loading $\left(\mathrm{W} / \mathrm{cm}^{2}\right)$ & 1,16 & 2,67 \\
\hline Temperature in the environment $\left({ }^{\circ} \mathrm{C}\right)$ & $60 \div 70$ & $100 \div 110$ \\
\hline Number of cycles & 1500 & 1500 \\
\hline Pressure force $(\mathrm{daN})$ & 1230 & 1230 \\
\hline Testing results & Test I & Test II \\
\hline Specific wearing $\left(\mathrm{cm}^{3} / 10 \mathrm{MJ}\right)$ & 0,59 & 0,73 \\
\hline \multicolumn{3}{|l|}{ Friction coefficient $\mu$} \\
\hline Friction coefficient waste (\%) & $-6 /+6$ & $-10 /+10$ \\
\hline
\end{tabular}

RESULT 2: from the laboratory testing of a clutch Dimensions: $\varnothing 350 / \varnothing 195 / 3,5$; Lining quality: T2

\begin{tabular}{|l|c|c|}
\hline \multicolumn{1}{|c|}{ Testing regime } & Test I & Test II \\
\hline Number of rotations $(1 / \mathrm{min})$ & 1600 & 1600 \\
\hline Moment of inertia $\left(\mathrm{kg} \cdot \mathrm{m}^{2}\right)$ & 4,42 & 10,22 \\
\hline Specific workload $\left(\mathrm{J} / \mathrm{cm}^{2}\right)$ & 46 & 107 \\
\hline Frequency of engagement $(1 / \mathrm{min})$ & 1,5 & 1,5 \\
\hline Specific caloric burden $\left(\mathrm{W} / \mathrm{cm}^{2}\right)$ & 1,16 & 2,67 \\
\hline Temperature in the environment $\left({ }^{\circ} \mathrm{C}\right)$ & $60 \div 65$ & $100 \div 110$ \\
\hline Number of cycles & 1500 & 1500 \\
\hline Pressure force $(\mathrm{daN})$ & 1230 & 1230 \\
\hline \multicolumn{1}{|c|}{ Testing results } & Test I & Test II \\
\hline Specific wearing $\left(\mathrm{cm}^{3} / 10 \mathrm{MJ}\right)$ & 0,48 & 0,65 \\
\hline Friction coefficient $\mu$ & & \\
\hline Friction coefficient waste $(\%)$ & $-7 /+6$ & $-9 /+10$ \\
\hline
\end{tabular}

Then tribological parameters were tested on the lining $\mathrm{T} 2$, manufactured on the basis of glass threads. Lining T2 
is made with impregnate and thread which provide good friction parameters and are validated experimentally. Lining $\mathrm{T} 1$ has impregnate which differs from the impregnate in lining $\mathrm{T} 2$ by different percentages of the components in its composition.
Both, basalt based lining with $\mathrm{T} 1$ quality and glass based lining with T2 quality were tested under normal (test I) and heavy (test II) loading. Results and comparison of tribological parameters for linings $\mathrm{T} 1$ and linings T2 are given in Fig. 4, diagrams D1 and D2, and also in the following tables, RESULT 1 and RESULT 2.
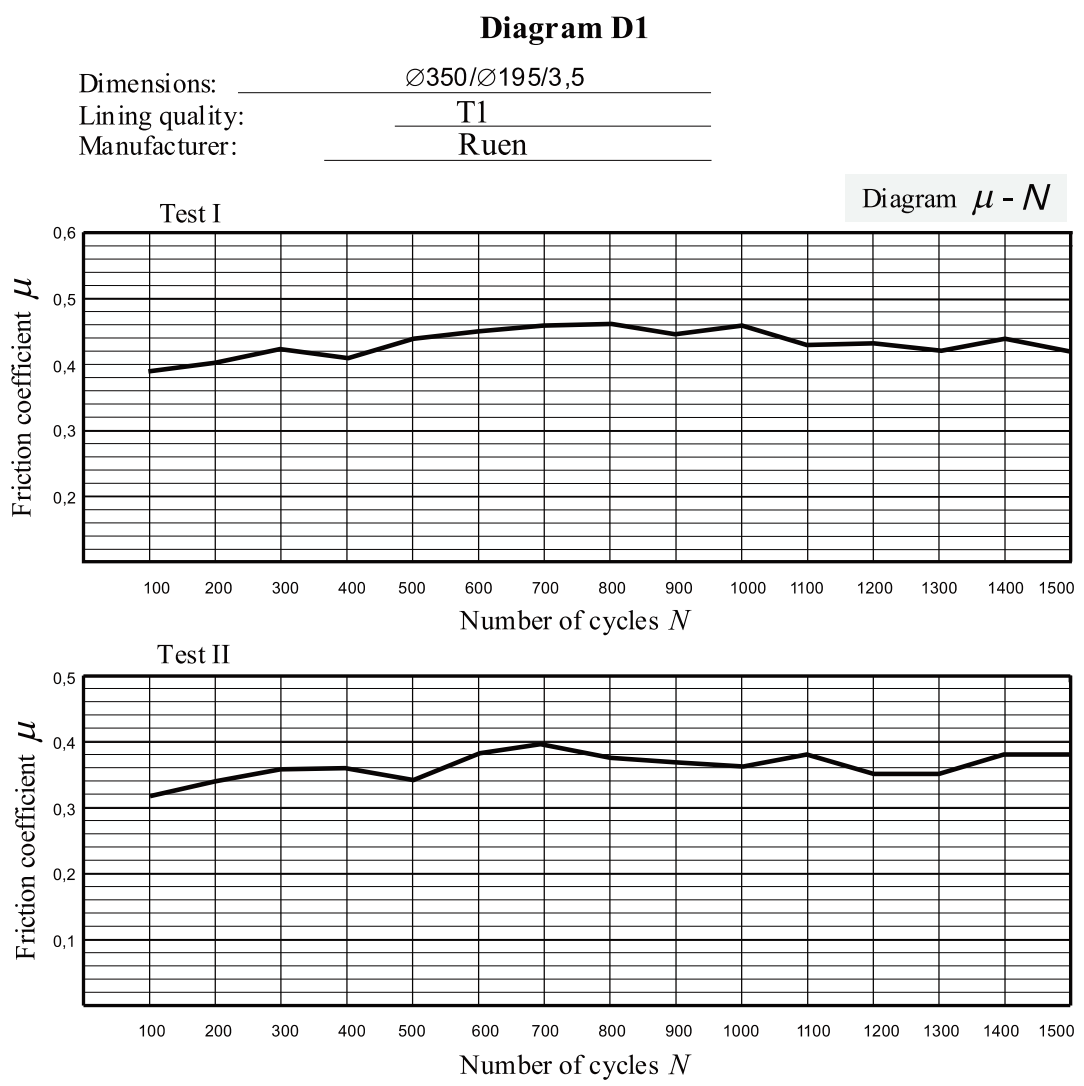

Diagram D2
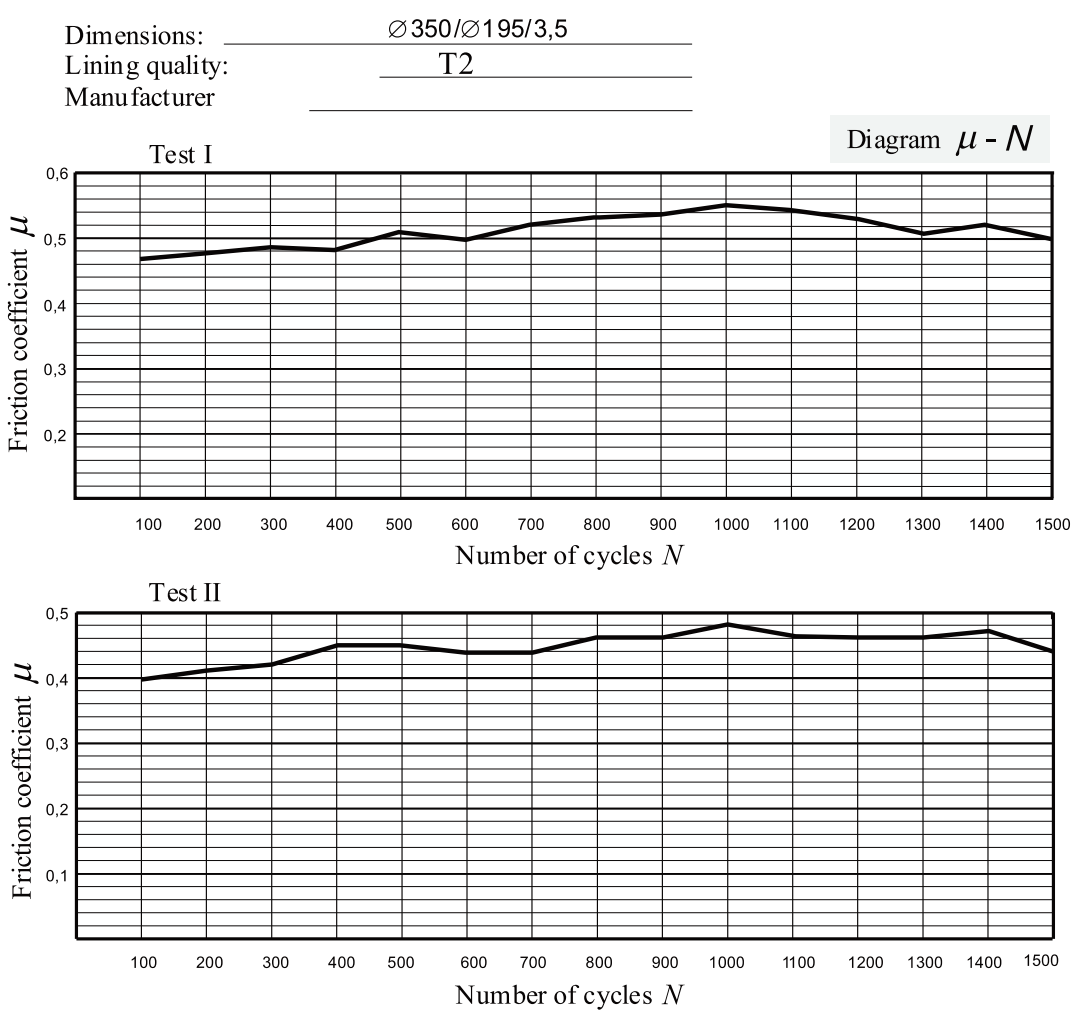

Figure 4 Results of linings with quality $\mathrm{T} 1$ and $\mathrm{T} 2$ 


\section{Discussion}

Lining specific wear depends on several factors, given in the test regimes, such as angular velocity, temperature, frequency of engagement, specific sliding work, etc. This experiment gives lining specific wear in relation of the number of cycles.

As can be seen from figure 4 tribologic parameters required from a friction lining (to satisfy bigger workload) according to the world norms are satisfied. Nevertheless it is seen that in normal or heavy conditions weaker results were obtained with the glass based linings for the same number of cycles and with the same rotation speed.

Considering the testing of the friction linings for motor vehicles and depending on the ratio of the substances in the material structure for friction linings manufactured on the basalt base, the following conclusion is made:

- The ratio of the components of the lining that satisfy the thermal test (test III - friction coefficient larger than 0,22 at thermal loading of $q=6 \mathrm{~W} / \mathrm{cm}^{2}$ ) from minimum of 50 cycles is determined.

\section{$\varnothing 350$ (mm)}

Thread $(52 \div 60 \%)$ :

- $\quad$ basalt $(66 \div 68 \%)$

- $\quad$ viscose $(2)(9 \div 11 \%)$

- copper (3-threads) $(20 \div 24 \%)$

Impregnate $(\mathbf{4 0} \div \mathbf{4 8} \%)$ :

- $\quad$ latex-1 $(37 \div 39 \%)$

- $\quad$ graphite $(6 \div 7 \%)$

- $\quad \operatorname{soot}(4 \div 5 \%)$

- $\quad$ sulphur $(14 \div 16 \%)$

- $\quad$ modifier (resins) $(18 \div 23 \%)$

- condenser $(3 \div 4 \%)$

- $\quad$ other $(7 \div 9 \%)$.

\section{Conclusion}

Beside the main benefit, i.e. good tribological parameters, there is the economic benefit. The economic perspective shows that the price is competitive on the market, because the basalt thread is cheaper than the glass thread.

The aim of the project is achieved through the previously described tests, and these results are applied in the manufacturer's program of CLL Ruen - Kochani.

Conditions for further advancement of this type of lining were created, i.e. in tribological parameters improvements regarding temperature, sliding velocity, specific pressure, frequency of engagement, etc. in order to obtain results of a greater lining quality.

\section{References}

[1] Öztürka, B.; Arslana, F.; Öztürk, S. Hot wear properties of ceramic and basalt fiber reinforced hybrid friction materials. // Elsevier: Tribology International. 40, 1(2007), pp. 37-48.

[2] Danev, D.; Kjosevski, M.; Simeonov, S. Influence of the specific sliding work on tribological parameters of friction linings for heavy vehicle clutches. // TTEM - Technics Technologies Education Management. 8, 4(2013), pp. 1889-1893.
[3] Simeonov, S.; Cvetkov, S.; Dimitrov, S.; Sovreski, Z. Influence of the number of the clutch engagement on the wearing of friction linings of clutches for motor vehicles. // Tehnički vjesnik - Technical Gazette. 19, 2(2012), pp. 447449.

[4] Colombo, C.; Vergani, L.; Burman, M. Static and fatigue characterization of basalt fiber reinforced composites. // Composite Structures. 94, 3(2012), pp. 1165-1174. DOI: 10.1016/j.compstruct.2011.10.007

[5] Danev, D.; Kjosevski, M.; Simeonov, S. Influence of the clutch engagement/disengagement to the friction lining lifetime in exploitation and laboratory conditions. // Proceedings of $24^{\text {th }}$ International Automotive Conference "Science and Motor Vehicles 2013" / Belgrade, 2013, pp. 402-408.

[6] Simeonov, S.; Cvetkov, S.; Danev, D.; Sovreski, Z.; Dimitrov, S. Impact of metal wire on the tribological parameters of the fiction lining. // Proceedings in Global Virtual Conference - The $1^{\text {st }}$ International Global Virtual Conference / 2013, pp. 643-645.

[7] Simeonov, S. Influence of the components of friction material linings structure on the performances of friction clutch for heavy motor vehicle. // PhD thesis, Skopje 1999.

[8] Arsenikj, Z. Development of methodology for laboratory tests of friction clutches for light motor vehicles. // Master Thesis / Belgrade, 1982.

\section{Authors' addresses}

Darko Danev, PhD

Faculty of Mechanical Engineering,

University "Ss. Cyril and Methodius" - Skopje

Karposh 2 bb, 1000 Skopje, Republic of Macedonia

E-mail: darko.danev@mf.edu.mk

\section{Simeon Simeonov, PhD}

Faculty of Mechanical Engineering,

University "Goce Delchev" - Stip

Krste Misirkov 10-A, 2000 Stip, Republic of Macedonia

E-mail: simeon.simeonov@ugd.edu.mk

Vase Jordanoska, MSc

Faculty of Mechanical Engineering,

University "Ss. Cyril and Methodius" - Skopje

Karposh 2 bb, 1000 Skopje, Republic of Macedonia

E-mail: vase.jordanoska@mf.edu.mk 